\title{
Factors Influencing Selection of Low Cost Airlines with Reference to Coimbatore Airport
}

\author{
R. Indra ${ }^{1 *}$ and C. Malleshwaran ${ }^{2}$ \\ ${ }^{1}$ Ph.D Scholar, Department of Commerce, Chikkana Government Arts College, Tirupur - 641602, Tamil Nadu, India; \\ indraeswari@gmail.com \\ ${ }^{2}$ Assistant Professor \& Head, Department of International Business, Chikkana Government Arts College, \\ Tirupur - 641602, Tamil Nadu, India
}

\begin{abstract}
Transport is one of the important infrastructures needed for the all round development of the nation. Among various ways of transport namely road, rail, air and waterways, the airways contributes more to the global network of the countries. The recent beginning of low cost air carriers in early 1900s, led to the improvement in its value chain with reduction in cost and excellent customer service. Industry specialists and consumers believe that low cost airlines have benefitted the industry by providing low fares and made air travel affordable and economy. In this background, the present study focuses on the factors influencing selection of Indian low cost airlines with reference to Coimbatore airport.
\end{abstract}

Keywords: Economy, Low cost airlines, Low fare and Service quality

\section{Introduction}

Aeronautics industry is one among the most significant ventures of any nation due to its financial and social practicality. The flying business not just adds to the Gross Domestic Product (GDP) of the nation and improves work measurements, but it also helps in residential and worldwide exchange and encourages numerous different organizations. The airline business interfaces individuals to individuals prompting social trade and improvement. The lowest private airlines provide economic comfort to the middle income group of passengers. The number of low cost airlines is quite increasing at a rapid pace. In this context, the present study attempts to know the factors influencing selection of low cost airlines by the passengers in Coimbatore Airport. The association between various exogenous variables and factors influencing the selection of low cost airlines is analyzed with Chi-square test. Further, the reason for selecting low cost airlines is examined with Henry Garrett Ranking Technique.

\section{Statement of the Problem}

The Indian aviation industry is one of the fastest growing industries in the world. As there is a vast liberalization of the Indian aviation sector, the aviation industry in India has undergone a rapid transformation. In this competitive environment, satisfying the customers, i.e., passengers will have a positive impact for long time survival. In order to hold and bring customers/passengers, the airlines are providing excellent services at low cost. Thus, an attempt has been made to analyze the factors influencing the passengers in selection of low cost airlines in Coimbatore airport.

\section{Review of Literature}

Fourie ${ }^{1}$ emphasized that South African business explorer working for enormous organizations utilized Full Service Airlines and South African Business voyagers with little to medium size organizations might want to utilize Low Cost Airlines. Assaf 2 inferred that airlines must embrace

*Author for correspondence 
benchmarking technique to play out a constant assessment of its presentation against the operational procedures. The elements like Load factor and Airlines size were identified with specialized productivity of the airlines. Yu Kyoung Kim et al., $\underline{\underline{3}}$ investigated the customer satisfaction of low cost carriers. The study suggested that airlines should concentrate on tangibles, responsiveness for enhancement of customer satisfaction and behavioral intentions. Climis Raghda ${ }^{4}$ studied the variables that influence customer retention in the airline industry by considering the service quality attributes namely, Perceived safety, Customer satisfaction, Loyal reward program, Relationship commitment and Customer loyalty. It was found that Reliability had high impact on Customer satisfaction and there exist a positive relationship between commitment and customer loyalty. Thapanat Buaphiban et al.,,$\frac{5}{}$ examined the passengers' behavior towards low cost carriers in Southeast Asia. It was revealed that there was a positive impact on passengers' intention whereas passengers' intention and perceived behavioral control had a positive impact on passengers' buying habit.

\section{Objectives of the Study}

To examine the association between exogenous variables of the respondents and airline chosen for travel.

To analyze the factors influencing the passengers in selection of low cost airlines.

\section{Research Methodology}

The present study has been carried out by selecting the sample through convenience sampling technique. The study uses both primary and secondary data. The primary data has been collected through a well framed questionnaire from 384 low cost airline passengers including domestic and international at Coimbatore airport.

\section{Analysis and Discussion}

\subsection{Profile of the Respondents}

The demographic profile of the respondents is examined by using Simple Percentage Analysis. The findings are shown in Table 1.

Table 1 shows that male (66.1\%) respondents are higher than female respondents. Most of the respondents fall under the age category of 31-40 years (35.4\%). Monthly earnings reflected higher as more number of respondents is earning
Rs.60000-80000. Most of the respondents (31.8\%) are under graduates and maximum respondents are self employed (22.4\%) and married (79.7\%).

Table 1. Profile of the Respondents

\begin{tabular}{|c|c|c|}
\hline Demographic Profile & $\begin{array}{c}\text { Number of } \\
\text { Respondents }\end{array}$ & Percentage \\
\hline \multicolumn{3}{|l|}{ Gender } \\
\hline Male & 254 & 66.1 \\
\hline Female & 130 & 33.9 \\
\hline Total & 384 & 100.0 \\
\hline \multicolumn{3}{|l|}{ Age of the Respondents } \\
\hline Below 30 years & 90 & 23.4 \\
\hline $31-40$ years & 136 & 35.4 \\
\hline $41-50$ years & 88 & 22.9 \\
\hline Above 50 years & 70 & 18.2 \\
\hline Total & 384 & 100.0 \\
\hline \multicolumn{3}{|l|}{ Monthly Earnings } \\
\hline Less than Rs.40000 & 54 & 14.1 \\
\hline Rs.40001-60000 & 122 & 31.8 \\
\hline Rs.60001-80000 & 128 & 33.3 \\
\hline Above Rs.80001 & 80 & 20.8 \\
\hline Total & 384 & 100.0 \\
\hline \multicolumn{3}{|l|}{ Educational Qualification } \\
\hline School level & 78 & 20.3 \\
\hline Diploma & 56 & 14.6 \\
\hline Under graduate & 122 & 31.8 \\
\hline Post graduate & 80 & 20.8 \\
\hline Professional degree & 48 & 12.5 \\
\hline Total & 384 & 100.0 \\
\hline \multicolumn{3}{|l|}{ Occupation } \\
\hline Educationalist & 18 & 4.7 \\
\hline Self employed & 86 & 22.4 \\
\hline Corporate official & 74 & 19.3 \\
\hline Government official & 28 & 7.3 \\
\hline Student & 18 & 4.7 \\
\hline Professional & 42 & 10.9 \\
\hline Home maker & 50 & 13.0 \\
\hline Others & 68 & 17.7 \\
\hline Total & 384 & 100.0 \\
\hline \multicolumn{3}{|l|}{ Marital Status } \\
\hline Single & 78 & 20.3 \\
\hline Married & 306 & 79.7 \\
\hline Total & 384 & 100.0 \\
\hline
\end{tabular}

Source: Computed 


\subsection{Type of Airline Chosen for Travel}

The type of airline chosen by the respondents for travel is classified as public and private and the results are shown in Table 2.

Table 2. Type of Airline Chosen for Travel

\begin{tabular}{|l|c|c|}
\hline $\begin{array}{c}\text { Type of Airline Chosen } \\
\text { for Travel }\end{array}$ & Frequency & Percentage \\
\hline Private Airline & 228 & 59.4 \\
\hline Public Airline & 156 & 40.6 \\
\hline Total & $\mathbf{3 8 4}$ & $\mathbf{1 0 0 . 0}$ \\
\hline
\end{tabular}

Source: Computed

Table 2 reveals that most of the respondents prefer to travel in private airlines (59.4\%) rather than Public airlines (40.6\%).

\subsection{Low Cost Airlines Preferred by the Respondents}

Table 3. Preference of Low Cost Airlines

\begin{tabular}{|l|c|c|}
\hline \multicolumn{1}{|c|}{ Airlines } & Frequency & Percentage \\
\hline Indigo & 126 & 32.8 \\
\hline Spice Jet & 114 & 29.7 \\
\hline Air India Express & 68 & 17.7 \\
\hline Scoot & 20 & 5.2 \\
\hline Air Arabia & 28 & 7.3 \\
\hline Air Asia & 28 & 7.3 \\
\hline Total & $\mathbf{3 8 4}$ & $\mathbf{1 0 0 . 0}$ \\
\hline
\end{tabular}

Source: Computed

Table 3 discloses that $32.8 \%$ of the passengers prefer Indigo, 29.7\% prefer Spice Jet, 17.7\% prefer Air India Express, $5.2 \%$ prefer Scoot and $7.3 \%$ of the passengers prefer Air Arabia and Air Asia equally. Hence, it can be concluded that majority of the respondents prefer Indigo to travel.

\subsection{Association between Exogenous Variables and Airline Chosen for Travel}

The association between various exogenous variables and airline chosen for travel is analyzed by framing the following null hypothesis and the same is tested with Chi-square test at $5 \%$ level of significance. The results are shown in Table 4 .

$\mathrm{H}_{0}$ : There is no significant association between exogenous variables (Gender, Age, Monthly Earnings, Educational Qualification, Occupation and Marital Status) and airline chosen for travel.
Table 4. Association between Exogenous Variables and Airline Chosen for Travel

\begin{tabular}{|l|c|c|l|}
\hline \multicolumn{1}{|c|}{$\begin{array}{c}\text { Exogenous } \\
\text { Variables }\end{array}$} & $\begin{array}{c}\text { Degrees of } \\
\text { Freedom }\end{array}$ & p-value & \multicolumn{1}{|c|}{ Result } \\
\hline Gender & 2 & .000 & Significant \\
\hline Age & 4 & .000 & Significant \\
\hline Monthly Earnings & 4 & .050 & Significant \\
\hline $\begin{array}{l}\text { Educational } \\
\text { Qualification }\end{array}$ & 5 & .001 & Significant \\
\hline Occupation & 8 & .000 & Significant \\
\hline Marital Status & 2 & .150 & Not Significant \\
\hline
\end{tabular}

Source: Computed

Table 4 reveals that there is a significant association between gender, monthly earnings, age, educational qualification, occupation of the respondents and the airline chosen by them.

\subsection{Factors Influencing the Passengers in Selection of Low Cost Airlines}

The factors influencing the passengers to choose low cost airlines is examined by considering low fare, covering large destinations, suitable flight schedule, on-time performance, comfort, discounts and offers and service quality. The most important influencing factor is determined by applying Henry Garrett Ranking Technique. The findings are shown in Table 5.

Table 5. Factors Influencing the Passengers in Selection of Low Cost Airlines

\begin{tabular}{|l|c|c|}
\hline \multicolumn{1}{|c|}{ Reasons } & Mean & Rank \\
\hline Low Fare & 3.45 & I \\
\hline Service Quality & 3.58 & II \\
\hline Covering Large Destinations & 5.08 & III \\
\hline Suitable Flight Schedule & 5.89 & IV \\
\hline On-Time Performance & 6.27 & V \\
\hline Comfort & 6.65 & VI \\
\hline Discounts and Offers & 7.27 & VII \\
\hline
\end{tabular}

Source: Computed

Table 5 infers that the most important factor influencing the passengers to select low cost airlines is low fare with the mean score of 3.45 followed by service quality (3.58), covering large destinations with mean value of 5.08 , suitable flight destination with mean score of 5.89, on-time performance (6.27), comfort (6.65) and discounts and offers (7.27). 


\section{Suggestions}

Based on the findings of the study, the following suggestions are given in the present study:

$>$ The passengers expect better service with low cost. Hence, the low cost airlines must enhance service quality with improved facilities.

$>$ The actual frequency of flights to some important destinations, the seating capacity offered and the operational standards have not been kept in pace with the growth rate of air traffic. Hence, the low cost airlines need to improve the flight frequency to various destinations.

\section{Conclusion}

The low cost airlines use their operation strategies to offer the low price for passengers. In order to maintain low air ticket fare, they reduce a large number of services. When the passengers are in need of any additional service, it becomes necessary for them to pay extra money. The requirement of more variety and quality services in air travelling would be difficult to convince low cost airline passengers to use their services. The reason is that low price for airlines usually provide the standard services with low cost that does not serve the higher quality services. However, as each kind of airline has different market segments, appropriate performance objectives and operation strategies are thus needed to encourage customers to select low cost airlines.

\section{References}

1. Fourie C, Lubbe B. Determinants of selection of full service airlines and low cost carriers - A note on business travelers in South Africa. Journal of Transport Management. 2006; 12 (2):98-102. https://doi.org/10.1016/j.jairtraman.2005.11.008

2. Assaf AG, Josiassen A. The operational performance of UK Airlines. Journal of Economic Studies. 2009; 38(1):5-16. https://doi.org/10.1108/01443581111096114

3. Kim YK, Lee HR. Customer satsfaction of low cost carriers. Tourism Management. 2011; 32: 235-43. https://doi. org/10.1016/j.tourman.2009.12.008

4. Raghda C. Factors affecting customer retention in the airline industry. Journal of Management and Business Administration. Central Europe, Sciendo. 2016; 24(4):49-69. https://doi.org/10.7206/jmba.ce.2450-7814.182

5. Buaphiban T, Truong D. Evaluation of passengers' buying behavior towards low cost carriers in Southeast Asia. Journal of Air Transport Management. 2017; 59:124-33. https://doi. org/10.1016/j.jairtraman.2016.12.003 